\title{
Evaluating Study for Visitor Experience and Loyalty at Jerash, Archaeological Site in Jordan
}

\author{
Ranea Qaddhat ${ }^{*}$ Hana Fayed ${ }^{2}$ Gada Wafik ${ }^{2}$ \\ 1-Ph.D. Student, Faculty of Tourism and Hotels, Fayoum University \\ 2-Professors, Faculty of Tourism and Hotels, Fayoum University \\ *E-mail of the corresponding: r.qaddahat@ju.edu.jo
}

\begin{abstract}
:
Visitor satisfaction with their experience and the resulting behavioral intentions or loyalty is vital for successful destination management and marketing. The aim of this study is to understand and evaluate the visitor experience and loyalty at Jerash, an archaeological site in Jordan, and to examine if there is a relationship between experience and loyalty at this site.

Research primary data was collected through the distribution of 360 questionnaires to Arab and foreign visitors. The methodology of the study included descriptive analysis, T. test, and F. test, and hypotheses analysis method (Correlation and Regression) by using SPSS. The results of this study showed that is a good visitor experience and loyalty at Jerash site. The relationship between experience and loyalty was also confirmed. Many recommendations have been made that will improve the level of visitor experience and satisfaction, and also raise the level of loyalty to the site Jarash.
\end{abstract}

Keyword: visitor, experience, loyalty, satisfaction, motivations, Jerash, Jordan.

DOI: $10.7176 /$ JTHS/40-07

\section{Introduction}

According to the World Travel and Tourism Council (WTTC), in 2017 the tourism sector contributed in direct Gross domestic product (GDP) growth Equivalent to 3.1\% and provided 6 million additional jobs in the sector. Travel \& Tourism contributed 7.6 US\$ trillion to the global economy (10.2\% of global GDP) and 292 million jobs in 2016. The sector accounted for $6.6 \%$ of total global exports and almost $30 \%$ of total global service exports (WTTC, 2017).

With transformations in GDP and in the dynamic socio-cultural world of tourism, tourists 'needs and expectations have become more diverse and complex (Ko Ko \& Supinit, 2016). So, countries, especially developing countries must focus on the tourism industry and managing themselves as a distinct tourist destination through management the basic elements in the tourism destination by providing the visitors with a quality experience which includes group identity, decision-making memory, leisure preferences, and meaningmaking strategies (Jawabreh,2017c; Omar et al,2018; Omar et al,2017; Qusay et al,2018;Falk, 2009).

The relationships between service quality, visitor satisfaction, visitor experience, and loyalty are fundamental and crucial issues should be taken into consideration in the tourism industry. Whereas the high service quality leads to satisfaction, as that the satisfaction leads to positive word-of-mouth, a good experience, and repeat visits, which affect on the financial performance (Abu Rumman et al,2013; Alananzeh et al,2018;Zabkar et al., 2010).

\section{Problem of the study}

Tourism is increasingly becoming a major contributor to the economic and social development in Jordan. Jerash regarded as a hub for tourists in the northern Jordan. It is regarded as the best-preserved city of the Decapolis. 
So far, Jerash like many tourist attractions in the country lacks a well-developed visitor management plan that ensures the best experience, satisfaction, and loyalty. At the same time preserves the integrity of the site, and promotes the sought benefits by all partners.

\subsection{This study is expected to answer the following question:}

1- What is the current situation of visitor experience at Jerash site?

2- What is the extent of visitors' loyalty to Jerash site?

3- Is there a direct or indirect relationship between the experience of visitors and their loyalty to Jerash site?

4- Is there an effect of visitors experience on their loyalty to Jerash site?

5- How can improve the level of visitors experience, satisfaction, and also raise their level of loyalty to the site Jerash

\section{Importance of the study}

The importance of research originated from:

1-The importance of tourism in the economic and social development in the Kingdom It is regarded as the second largest contributor to the GDP and the major contributor to alleviating poverty and reducing unemployment.

2-Jerash is regarded as the best-preserved city of the Decapolis. It is the main touristic site in northern Jordan and the second most attractive site after Petra. Efforts are exerted to nominate Jerash as a world heritage site.

3- Adopting a suitable plan to enhance services and facilities which play a key role in upgrading the level of visitor experience, satisfaction, and also raising their level of loyalty to the site Jerash, and contribute to the socio-economic sustainable development of Jerash as a tourist attraction.

\section{Objectives of the study}

1- Evaluate the current quality of visitor experience in Jerash site.

2- Identifying the level of visitor loyalty to Jerash site.

3- Analysis visitor profile (Nationality, age, social status, purpose and frequency of visit, etc.)

4- Examine the relationship between experience and loyalty at this site.

5- Providing suitable recommendations that contribute to upgrading the level of visitor's experience, satisfaction, and also raising their level of loyalty to Jerash site.

\section{Literature Review}

(Chiang, 2016), "Examining the Relationships between Destination Image, Place Attachment, and Destination Loyalty in the Context of Night Markets". This study focused on investigating the destination image, place attachment, and destination loyalty among visitors to night markets. The methodology of this study depended on 474 effective questionnaires were collected from visitors to the three well-known Tainan night markets in Taiwan. The results showed that destination image has a significant direct effect on place dependence, place identity, and destination loyalty. Additionally, place identity is the antecedent that has an effect on destination loyalty.

(Fu Chen and Shian Chen, 2016) in "Experience quality, perceived value, satisfaction and behavioral intentions for heritage tourists" examines the visitor experience of heritage tourism and investigates the relationships between the quality of those experiences, perceived value, satisfaction, and behavioral intentions. The methodology of this study depended on a survey that conducted at four main heritage sites in Tainan, Taiwan. Using structural equation modeling (SEM) technique, the results reveal the direct effects of the quality of experience on perceived value and satisfaction. However, it is the indirect and not direct effects of the quality of experience that impact on behavioral intentions when mediated by perceived value and satisfaction. 
he depends on Application of the structural equation model indicates that festival quality dimensions as souvenirs, food, program, and facilities affect value, which then contributes to visitors' satisfaction and loyalty.

(Shik Yoon, 2010)in "Measuring festival quality and value affecting visitors' satisfaction and loyalty using a structural approach" examines in his study if there is an impact of the quality dimensions on perceived value, which Certainly affects satisfaction and loyalty, in the context of the Punggi Ginseng festival.

(Z`abkar et al., 2010), in "Modeling perceived quality, visitor satisfaction and behavioral intentions at the destination level" focus in their research in exploring the complex relationships between quality of a tourist destination, satisfaction with their experience and the resulting behavioral intentions by using structural equation modeling, The structural model was tested on a sample of 1056 visitors at four tourist destinations in Slovenia. they confirm in their study the link between satisfaction and behavioral intentions was also confirmed. These research findings contribute to a better understanding of which behavioral mechanisms and factors represent a viable basis for increasing customer retention. he depends on Application of the structural equation model indicates that festival quality dimensions as souvenirs, food, program, and facilities affect value, which then contributes to visitors' satisfaction and loyalty.

(Barnes et al., 2014) in "Destination brand experience and visitor behavior: Testing a scale in the tourism context" examines destination branding via a new conceptualization, destination brand experience (DBE), which provides a more holistic and unified view of the destination brand. It examines the direct and mediated role of DBE components in determining revisit intentions and word-of-mouth recommendations. The findings suggest that DBE is an important determinant of all study outcomes.

(Cole, 2009) in" Examining the festival attributes that impact visitor experience, satisfaction and revisit intention" examined the impacts of a downtown festival's attributes on visitors' overall experience, their levels of satisfaction and intentions to return.

\subsection{Visitor Loyalty}

Behavioral intentions and loyalty have been used in marketing and tourism. Loyalty has been a crucial objective of service providers since the high retention of customers or a low defection rate determines long-term profit levels (Shik Yoon et al., 2010).

Loyalty can reduce cost; create positive word-of-mouth and increase purchase frequency and amount. In the field of tourism and recreation, destination loyalty is an important issue to investigate (Al-Hussein et al, 2015: ALsarayreh et al, 2011; Al-ShawagfihF et al, 2015;Chiang, 2016).

Understanding which factors increase loyalty is good information for tourism marketers and managers. Some researchers measure loyalty by using two approaches; the intention the intention to revisit and the willingness to recommend it to friends and relatives (Naidoo, 2011; Amyan and Jawabreh, 2011; Bazazo et al, 2017; Jawabreh, 2014a). Other researchers have used four items to measure loyalty; intention to revisit, saying positive things, recommending the destination to others, and willingness to pay more (Chiang, 2016). Shik Yoon mentions another indicator to measure loyalty or behavioral intention is; repurchase intention and a high tolerance for a price premium.

On the other hand (Cossío et al) measures loyalty by using other indicators; expectations, service quality, satisfaction, destination image, intention to revisit, and intention to recommend the destination (Cossío et al., 2018).

All items for the three constructs were measured (intention to revisit, intention to recommend the destination will spend more time in the next visit) on a five-point Likert-type scale which ranging from (1) strongly disagree to (5) strongly agree. The questionnaire also contained a number of questions related to demographic variables.

\subsection{Visitor Experience}

The experience is defined as "the individuals' subjective mental state during a service encounter" (Verdugo, 2016, p: 227). There are four dimensions to scale the experience include; sensory, effective, intellectual, and behavioral (Brakus, ET AL., 2009). The tourist experience encompasses interaction between individuals and marked by psychological factors, and social experience (Jawabreh and Al Sarayreh,2017; Verdugo, 2016). 
Every visitor has own set of attitudes, expectation, prejudices, and values the experience is different for everyone. Experience cannot be standardized, because it depends on the way in which the experience is perceived by those different genders, age, and race (Shackley, 2001).

The primary motivator for visit depends on the issue of experience (Shackley, 2001). And determining the quality of the experience depends on the individual cognition and feelings about the experience. Experiences are a powerful driver of future behavior because they determine customer satisfaction (Jawabreh et al,2015;Verdugo et al., 2016). Goulding confirms that satisfaction management requires an understanding of visitor expectations, and experiences (Goulding, 2000).

Shackly mentions in his study to four stages that relates to experience of visiting site as: anticipation and information gathering, the journey to the site which may be related to special activities, visitor experience's rest is based on the time spent at the site which affected by previous perceptions whether during, and before the journey, and also the return journey. They may be intangible, physical, or maybe the aggregation of tangible artifacts (Shackley, 2001; Jawabreh et al,2018).

\subsection{Jerash}

Jerash has located about $48 \mathrm{~km}$ from the capital of Jordan, Amman. It is in the north of the Hashemite Kingdom of Jordan. Jerash can be accessed from Amman which is east and south of Jerash, Ajloun which is north and Irbid which is north-west of Jerash. Jerash is located in a green valley with water running in it (Local Development Unit and the Geology researchers, 2015).

\subsubsection{Archaeological site at Jerash}

Jerash has an archaeological area of about (1.5km*1.0km) (Al Adwan, 2015).

The city is one of the most conserved Roman ancient cities in the world (Khrisat et al., 2012). Outside of Rome, Jerash is the oldest and most complete Roman cities left standing today, and it is ranked as one of the most important sites in Jordan at number two, just beneath Petra (Luck, 2011). Jerash was built in the $2^{\text {nd }}$ century B.C, in 63 B.C, by the Roman emperor, Pompey (Boham, 2002).

There are various artifacts and structures that date back to the Paleolithic tile in the Islamic period. (Khrisat et al, 2012). Outside of Italy, Jerash is the largest and most well-preserved sites that display the Roman architecture of Imperial Rome. However, several earthquakes in 749 AD did serious damage to Jerash and quickened the decline of the city and its structures (; Jawabreh,2017b ; Al Rawashdeh, et al., 2013).

\subsubsection{History of Jerash (Archaeological Site)}

There are outstanding records that reveal Jerash has had human settlement related to the Neolithic period (8000 B.C.) (Al Bayari, 2005, Al Adwan, 2015). The settlement continued in the Chalcolithic period as well (4500 - 3200 B.C.) (Damgaard \& Blanke, 2004). During the Bronze Age, inhabitation spread quickly near the south-eastern part of Jerash, known by Flint Hill. In (1200-2300B.C.) in the Iron Age, habitation spread further, extending to the southern wall of Jerash near the historic museum (Al Adwan, 2015).

Until the Hellenistic Period (333-63B.C), the land had periodic habitation (Watts, 1997). Jerash dates back to this time period and was known as Antioch on the Chrysorhoas (Damgaard \& Louise, 200).

In 63 B. C., the Roman General, Pompey, conquered Jerash. (Al Bayari, 2005). Therefore, Jerash became a part of Decapolis, ten cities that benefited from one another in terms of agriculture, commercial and technical life, and business relationships with Arabs Nabataeans during the first century B.C. numerous theatres, temples, horse racing fields, and ponds were built (Local Development Unit and the Geology researchers, 2015).

During the Islamic Period (636 AD), the settlement continued. Due to the excavations, evidence of architectural remnants of the Umayyad period remains. In the eighth century AD (the Abbasid Period) Jerash's economic conditions deteriorated as a result of the distance from the center of the caliphate in Baghdad (Local Development Unit and the Geology researchers, 2015). There are Umayyad structures located north of the south decomanos and west of the south Tetrakonia that consist of shops along the street (Walmsley, 2002).

Today, the archaeological features are destinations visitors, including travelers, tourists, and students, from all over the world want to see. Surpassing several ages, since the age of Greece, Roman, then the era of the Islamic conquest, Jerash has survived (Local Development Unit and the Geology researchers, 2015). 


\subsubsection{Main Features at Jerash Site}

Currently, the archaeological site of Jerash contains impressive remains: the 'Oval Piazza', the great columned avenues, the Temple of Zeus, the Temple of Artemis, the Nymphaeum, the Macellum, a hippodrome, two tetrapylons (one of which has been completely reconstructed), and two theatres as in figure 1. In addition to the Roman remains, a number of Byzantine churches, many elaborately decorated with mosaics, have survived (Damgaard \& Blanke, 2004).

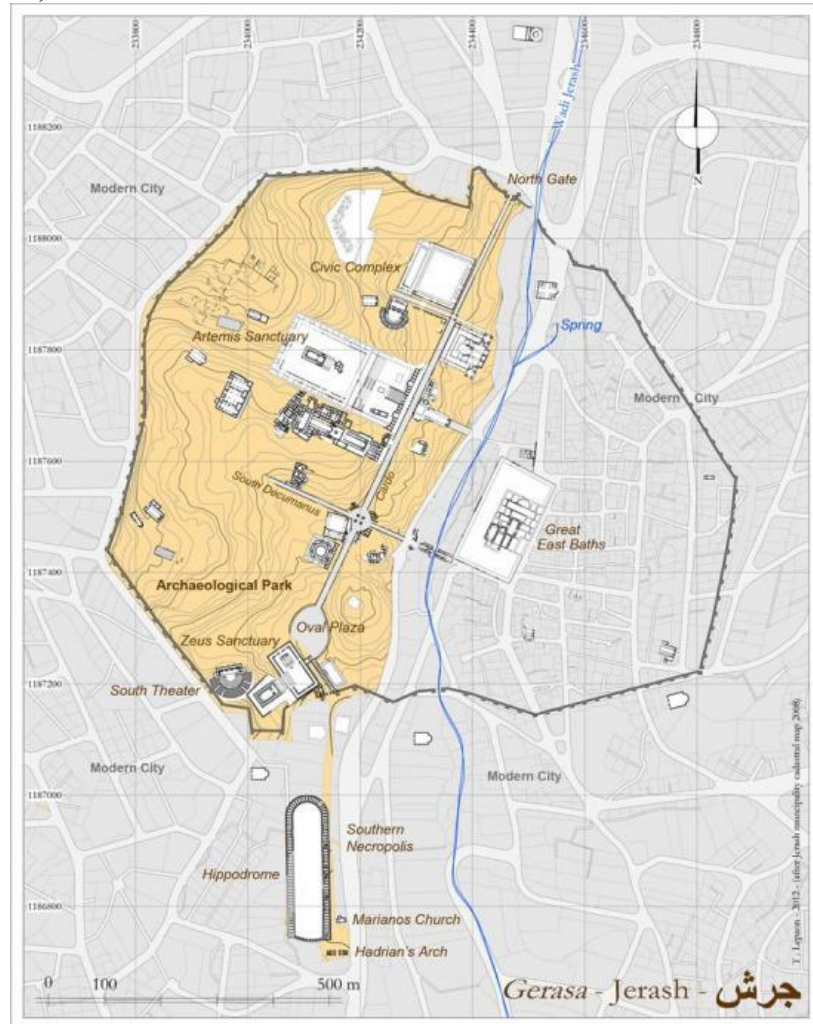

Figure 1: Map showing plan of the archaeological site in Jerash (source: Augé, 2013, p: 160)

\subsubsection{Jerash and World Heritage list}

There are three Jordanian cultural sites listed on the world heritage List: Petra in1985, Quseir Amra in 1985 and Umm er- Rasas In 2001 (Darabseh, 2010). The Jordanian government nominated the site of Jarash to the World Heritage Committee for listing in 1984, but it was postponed the nomination in 1985 due to these factors:

(1) Lack of information about the boundary of the Jerash site.

(2) Lack of a site management plan.

(3) The uncertainty of the harmonist of the site's restoration policy with the international standards.

After preparing all the requested information the Jordanian government nominated the site of Jarash to the World Heritage Committee for listing again, but the Heritage Committee in 1986 postponed the nomination after the expansion of the site's buffer zone, and after interest to the archaeological remains under the modern city, and also after stopping the unscientific works at the site.

In 1993, the Jordanian government submitted the documentation to the World Heritage Center in responding to their requirement, but the subject was postponed to 2004 when the site of Jarash has been on the World Heritage Tentative List (Myers et al, 2010) with another ten sites in Jordan were submitted on the same list (Darabseh, 2010).

\subsubsection{Jerash Values and Significance}

Any site management plans should be based on the values of the site The positive characteristics that Jarash has provided or will provide in the future might be are linked to social, scientific, spiritual, aesthetic, or 
economic value, the scientific and aesthetic values are protected by the Jordanian Law of Antiquities. The significance of the site of Jerash (overall importance of the archaeological site) is determined by the totality of the Jerash site values and its importance in relation to other similar sites (Myers et al, 2010).

\section{Methodology}

\subsection{Hypotheses}

H1: There is a good relationship between visitor experience and loyalty.

\subsection{Data Collection:}

Literature data will be raised from Arabic and foreign secondary sources related to the research subject (books, articles, etc.) that related to destination management, site management, and in visitor experiences, behavior, motivations, satisfaction, and loyalty.

\subsection{Field Work:}

Primary information will be collected through the following study tools:

$>$ A questionnaire survey contains (81) closed questions and (3) open-ended questions distributed among a sample of Arab and foreign visitors at Jeresh archaeological site, between 19th October to 4th November 2018, daily for 15 days, from 8.00 am to $5.30 \mathrm{pm}$.

A total of 418 questionnaires were distributed among Arab and foreign visitors (136 were distributed among the Arab visitors and 282 were distributed among the foreign visitors). One by one was collected directly after being filled by the visitors. 360 questionnaires ( 240 among the foreign, and 120 among the Arab) were analyzed on the basis of (SPSS - V-22). And 58 questionnaires were rejected (16 that was distributed among the Arab and 42 distributed among the foreign)

$>$ Direct personal observation to assess the current situation at Jerash.

\section{Data Analysis:}

The questionnaires were analyzed on the basis of (SPSS - V- 22). This study adopts a descriptive analytical approach that reviews the current situation of visitor experience and loyalty. And also adopts T. test and F. test, and hypotheses analysis method (Correlation and Regression) by using SPSS to identify statistical relations related to visitor experience and loyalty to Jerash site.

Community and Sample of Study:

Community of Study: all Jeresh site visitors during the year 2018/2019.

This research depends on the random sample for data collection, the sample size is (360) Arab and foreign Jerash visitors (240 Arab visitors, and 120 foreign visitors), that they were 18 and over years old, who visited Jerash between Octobers to November 2018.

\subsection{Reliability Analysis}

Table1. Reliability Analysis

\begin{tabular}{|l|l|l|}
\hline Cronbach's Alpha & N. items & N. cases \\
\hline 0.955 & 90 & 360 \\
\hline
\end{tabular}

Reliability Analysis is used to the questionnaire items. The value of Cronbach's Alpha is $(0.955>0.70)$, which indicates that questionnaire items are highly related to each other and that the items have relatively high internal consistency. It is known that a reliability coefficient of .70 or higher is considered "acceptable" in most social science research situations Furthermore, this result is considered an overall index of the repeatability and internal consistency of the questionnaire as a whole that makes sure of the results.

\subsection{Descriptive Analysis}


Table2. Descriptive Analysis for indicators of Visitor Experience

\begin{tabular}{|c|c|c|c|c|c|c|c|c|c|}
\hline \multirow[b]{2}{*}{ Item } & \multicolumn{5}{|c|}{ Frequencies } & \multicolumn{2}{|l|}{ Mean } & \multirow{2}{*}{$\begin{array}{l}\text { Std. } \\
\text { Deviation }\end{array}$} & \multirow{2}{*}{$\begin{array}{l}\text { Varia } \\
\text { nce }\end{array}$} \\
\hline & $\begin{array}{l}\text { S. } \\
\text { Disagree }\end{array}$ & Disagree & $\begin{array}{l}\text { Neutr } \\
\text { al }\end{array}$ & Agree & S. Agree & $\begin{array}{l}\text { Statist } \\
\text { ic }\end{array}$ & $\begin{array}{l}\text { Std. } \\
\text { Error }\end{array}$ & & \\
\hline $\begin{array}{lll}\text { It was a } & \text { great } \\
\text { experience. } & & \end{array}$ & $\begin{array}{l}3 \\
0.8\end{array}$ & $\begin{array}{l}9 \\
2.5\end{array}$ & $\begin{array}{l}53 \\
14.7\end{array}$ & $\begin{array}{l}133 \\
36.9\end{array}$ & $\begin{array}{l}162 \\
45.0\end{array}$ & 4.23 & 0.045 & 0.850 & 0.722 \\
\hline $\begin{array}{l}\text { I felt I should have } \\
\text { visited Jerash before. }\end{array}$ & $\begin{array}{l}9 \\
2.5\end{array}$ & $\begin{array}{l}16 \\
4.4\end{array}$ & $\begin{array}{l}100 \\
27.8\end{array}$ & $\begin{array}{l}117 \\
32.5\end{array}$ & $\begin{array}{l}118 \\
32.8\end{array}$ & 3.89 & 0.053 & 0.999 & 0.998 \\
\hline $\begin{array}{l}\text { I felt an emotional } \\
\text { connection with the } \\
\text { things I saw. }\end{array}$ & $\begin{array}{l}7 \\
1.9\end{array}$ & $\begin{array}{l}14 \\
3.9\end{array}$ & $\begin{array}{l}99 \\
27.5\end{array}$ & $\begin{array}{l}126 \\
35.0\end{array}$ & $\begin{array}{l}114 \\
31.7\end{array}$ & 3.91 & 0.050 & 0.957 & 0.916 \\
\hline $\begin{array}{l}\text { I am happy about my } \\
\text { decision to visit Jerash. }\end{array}$ & $\begin{array}{l}6 \\
1.7\end{array}$ & $\begin{array}{l}7 \\
1.9\end{array}$ & $\begin{array}{l}45 \\
12.5\end{array}$ & $\begin{array}{l}119 \\
33.1\end{array}$ & $\begin{array}{l}183 \\
50.8\end{array}$ & 4.29 & 0.046 & 0.881 & 0.777 \\
\hline $\begin{array}{l}\text { I felt scenes of wonder } \\
\text { or awe. }\end{array}$ & $\begin{array}{l}5 \\
1.4\end{array}$ & $\begin{array}{l}9 \\
2.5\end{array}$ & $\begin{array}{l}67 \\
18.6\end{array}$ & $\begin{array}{l}119 \\
33.1\end{array}$ & $\begin{array}{l}160 \\
44.4\end{array}$ & 4.17 & 0.048 & 0.911 & 0.830 \\
\hline $\begin{array}{l}\text { I had an enjoyable } \\
\text { experience. }\end{array}$ & $\begin{array}{l}6 \\
1.7 \\
\end{array}$ & $\begin{array}{l}8 \\
2.2 \\
\end{array}$ & $\begin{array}{l}49 \\
13.6\end{array}$ & $\begin{array}{l}124 \\
34.4\end{array}$ & $\begin{array}{l}173 \\
48.1\end{array}$ & 4.25 & 0.047 & 0.892 & 0.795 \\
\hline $\begin{array}{l}\text { I received a good } \\
\text { knowledge about the } \\
\text { site. }\end{array}$ & $\begin{array}{l}4 \\
1.1\end{array}$ & $\begin{array}{l}10 \\
2.8\end{array}$ & $\begin{array}{l}59 \\
16.4\end{array}$ & $\begin{array}{l}142 \\
39.4\end{array}$ & $\begin{array}{l}145 \\
40.3\end{array}$ & 4.15 & 0.046 & 0.870 & 0.757 \\
\hline $\begin{array}{l}\text { The experience was } \\
\text { engaging. }\end{array}$ & $\begin{array}{l}3 \\
0.8\end{array}$ & $\begin{array}{l}7 \\
1.9\end{array}$ & $\begin{array}{l}46 \\
12.8\end{array}$ & $\begin{array}{l}150 \\
41.7\end{array}$ & $\begin{array}{l}154 \\
42.8\end{array}$ & 4.33 & 0.090 & 1.707 & 2.915 \\
\hline $\begin{array}{l}\text { The visit achieved my } \\
\text { perceptions and } \\
\text { expectations. }\end{array}$ & $\begin{array}{l}6 \\
1.7\end{array}$ & $\begin{array}{l}10 \\
2.8\end{array}$ & $\begin{array}{l}39 \\
10.8\end{array}$ & $\begin{array}{l}160 \\
44.4\end{array}$ & $\begin{array}{l}145 \\
40.3\end{array}$ & 4.19 & 0.045 & 0.859 & 0.739 \\
\hline $\begin{array}{l}\text { I got value for the } \\
\text { money spent. }\end{array}$ & $\begin{array}{l}4 \\
1.1\end{array}$ & $\begin{array}{l}9 \\
2.5\end{array}$ & $\begin{array}{l}54 \\
15.0\end{array}$ & $\begin{array}{l}154 \\
42.8\end{array}$ & $\begin{array}{l}139 \\
38.6\end{array}$ & 4.16 & 0.045 & 0.850 & 0.722 \\
\hline $\begin{array}{l}\text { I discovered some new } \\
\text { information. }\end{array}$ & $\begin{array}{l}3 \\
0.8\end{array}$ & $\begin{array}{l}10 \\
2.8\end{array}$ & $\begin{array}{l}40 \\
11.1\end{array}$ & $\begin{array}{l}140 \\
38.9\end{array}$ & $\begin{array}{l}167 \\
46.4\end{array}$ & 4.28 & 0.044 & 0.834 & 0.696 \\
\hline Total & & & & & & 4.168 & 0.055 & 0.964 & 0.987 \\
\hline
\end{tabular}

The table number (2) shows the first ranking for the statement (The experience was engaging) since about (304) respondents with the rate of (84.5) \% of their answers locate between agree and strongly agree, and this is supported by the mean degree (4.33). The result of Std. Error of Mean is about $(0,090)$ it is less than the whole one, which means there is matching between the sample mean and community mean, so the mean value is representative for the real one. But the Std. Deviation and the variance respectively about (1.707) (2.915) are more than the whole one which means there somehow dispersion in the respondents' answers, the value of neutral about (12.8\%) emphasis this outcome. So the results ensure that there is to some degree hesitate between respondents to answer this question. Accordingly, the visitor's experience was not engaging enough.

Then, followed by the statements (I am happy about my decision to visit Jerash), and (I discovered some new information). The results show that the respondents' answers are slightly more than half, between agree and strongly agree, and the means in order (4.29) (4.28). This has been confirmed by Std. Error of Mean is about $(0,046)(0,044)$, it is less than the whole one, which means that there is matching between the sample mean and community mean, so the mean value is representative for the real one. As in the Std. Deviation (0.881) (0.834), and the variance respectively about $(0.777)(0.696)$ are less than the whole one which means there is no dispersion in the respondents' answers. So the results ensure that the visitors were happy about their decision to visit Jerash. Also, the visitor discovered some new information.

Came after that closely the statement (I discovered some new information) since about (82.5) \% of respondents' answers locate between agree and strongly agree. Also, the statement (It was a great experience) is about (81.9) \% of respondents' answers locate between agree and strongly agree, and this is supported by the mean in order (4.25) (4.23). Emphasize this outcome the result of Std. Error of Mean is about $(0,047)(4.045)$, it is less than the whole one, which means that there is matching between the sample mean and community mean, so the mean value is representative for the real one. As in the Std. Deviation respectively about (0.892) (0.850) and the variance respectively about (.795) (.722) are less than the whole one which means there is no dispersion 
in the respondents' answers. So the results ensure that the visitors had an enjoyable experience, and it was a great experience for them.

Then closely the statements (The visit achieved my perceptions and expectations), (I felt scenes of wonder or awe), (I got value for money spent) and also (I received a good knowledge about the site). The respondents' answers locate between agree and strongly agree, and this is supported by the means degree in order (4.19) (4.17) (4.16) (4.15). Also, that emphasized by the result of Std. Error of Mean it is less than the whole one, which means that there is matching between the samples mean and community mean, so the mean value is representative for the real one. Also the Std. Deviation and the variance are less than the whole one which means there is no dispersion in the respondents' answers. So the visit achieved visitors perceptions, also they felt scenes of wonder or awe expectations, at the same time they got value for money spent, and they received a good knowledge about the site.

Then came later the statements (I felt an emotional connection with the things I saw), and also (I felt I should have visited Jerash before). The results show that the respondents' answers are more than half between agree and strongly agree, and the mean in order (3.91) (3.89), and the Std. error about $(0.050)(0,053)$ is less than the whole one, and this is a good indicator since the mean is representative for the real mean in the community. Also, the standard deviation (0.957) (0.999) and variance $(0.916)(0,998)$ are high, and near to whole one, this confirms there is a slight dispersion in respondents' answers Consequently, visitors were not sure of their emotional connection with the things they saw, and they were not sure about their feel that they should have visited Jerash before

The average of the mean for all items of visitor experience variable about (4.16) is located between agree and strongly agree, this indicates that there is a good visitor experience at Jerash site, The average of Std. Error of Mean is about (0.055) which is less than the whole one, This result assures that there is an agreement between the sample mean and community mean, On the other hand, the results of the average of standard deviation (0.964), and the average of the variance is about (0.987) are less than the whole one, but it is high, which means there is a slight dispersion. Based on these findings, it is clear that there is a good visitor experience at Jerash site, but it is not high.

As a summary of the above we can say that visitor experience is great and enjoyable, As that visitors received a good knowledge about the site, also their perceptions and expectations were achieved, as well as they got value for money spent, also visitors felt an emotional connection with the things they saw, and they felt they should have visited Jerash before. But this experience has not reached to the level that makes it engaging. This due to the level of services and facilities is not high, and the activities which available at the site are limited so did not make the experience more enjoyable. In addition, the behavior of both employees and visitors has played a major role in judging the quality of the visitor experience, which requires effective management of such behaviors.

Table3. Descriptive Analysis for indicators of Visitor Loyalty

\begin{tabular}{|c|c|c|c|c|c|c|c|c|c|}
\hline \multirow[b]{2}{*}{ Item } & \multicolumn{5}{|c|}{ Frequencies } & \multicolumn{2}{|l|}{ Mean } & \multirow[b]{2}{*}{$\begin{array}{l}\text { Std. } \\
\text { Deviati } \\
\text { on }\end{array}$} & \multirow[b]{2}{*}{ Variance } \\
\hline & $\begin{array}{l}\text { S. } \\
\text { Disagr } \\
\text { ee }\end{array}$ & Disagree & $\begin{array}{l}\text { Neutr } \\
\text { al }\end{array}$ & Agree & S. Agree & Statistic & $\begin{array}{l}\text { Std. } \\
\text { Error }\end{array}$ & & \\
\hline $\begin{array}{l}\text { I will } \\
\text { recommend } \\
\text { close friends } \\
\text { and relatives to } \\
\text { visit Jerash. }\end{array}$ & - & $\begin{array}{l}9 \\
2.5\end{array}$ & $\begin{array}{l}36 \\
10.0\end{array}$ & $\begin{array}{l}134 \\
37.2\end{array}$ & $\begin{array}{l}181 \\
50.3\end{array}$ & 4.36 & 0.040 & 0.766 & 0.586 \\
\hline $\begin{array}{l}\text { I intend to visit } \\
\text { Jerash again }\end{array}$ & $\begin{array}{l}7 \\
1.9\end{array}$ & $\begin{array}{l}37 \\
10.3\end{array}$ & $\begin{array}{l}115 \\
31.9\end{array}$ & $\begin{array}{l}96 \\
26.7\end{array}$ & $\begin{array}{l}105 \\
29.2\end{array}$ & 3.71 & 0.056 & 1.056 & 1.115 \\
\hline $\begin{array}{l}\text { I will spend } \\
\text { more time in } \\
\text { the next visit to } \\
\text { Jerash. }\end{array}$ & $\begin{array}{l}12 \\
3.3\end{array}$ & $\begin{array}{l}43 \\
11.9\end{array}$ & $\begin{array}{l}98 \\
27.2\end{array}$ & $\begin{array}{l}103 \\
28.6\end{array}$ & $\begin{array}{l}104 \\
28.9\end{array}$ & 3.68 & 0.059 & 1.113 & 1.239 \\
\hline Total & & & & & & 3.91 & $\begin{array}{l}0.051 \\
6\end{array}$ & 0.97 & 0.98 \\
\hline
\end{tabular}


The table number (3) shows that the first ranking for the statement (I will recommend close friends and relatives to visit Jerash) with percentage about $87.5 \%$ of respondents' answers locate between agree and strongly agree, and this clear in mean degree (4.36), that indicates to a twist of the information to a positive direction towards the right. Also, more emphasis is the result of Std. Error of Mean is about $(0,040)$, it is less than the whole one, which means that there is matching between the sample mean and community mean, so the mean value is representative for the real one. In addition, the Std. Deviation and the variance respectively about (0.766) (0.586) are less than the whole one, which means there is no dispersion in the respondents' answers. So the results ensure that the visitor will recommend close friends and relatives to visit Jerash.

Then followed by statement (I intend to visit Jerash again), and the statement (I will spend more time in the next visit to Jerash), the results show that the respondents' answers are more than half, between agree and strongly agree, and the mean in order (3.71) (3.68), and the Std. Error of Mean is about (0.056) (0.059) less than the whole one. Since the mean value is representative for the real mean in the community. However, the standard deviation (1.056) (1.113) and variance (1.115) (1.239) are high, and more than the whole one, this confirms there is a dispersion in the respondents' answers. Consequently, visitors are unsure of their decision to repeat the visitation and spending more time in the next visit.

This is compatible with what was mentioned by Cossío-Silva (2018, p: 5) that the visitors have a loyalty to the site, and they interested in recommend friends and relatives to visit a site more than an interest in repeating the visitation or spending more time in the next visit.

The average of the mean for all items of visitor loyalty variable is (3.91), this indicates that there is the loyalty of visitors to Jerash site. And the average of Std. Error of Mean is about (0.0516) which means results are consistent with actual reality. The more positive finding we find that the results of the average of standard deviation (0.97) and the average of the variance are about (0.98) less than the whole one but it is high, which means there is a slight dispersion among respondents about these results. Based on these findings, it is clear that there is loyalty to visitors to Jerash site but it is not high.

Table 4.Descriptive Analysis for indicators of Visitor Profile

\begin{tabular}{|c|c|c|c|c|c|c|c|}
\hline \multirow{2}{*}{ Item } & \multirow{2}{*}{\multicolumn{3}{|c|}{ Frequencies }} & \multicolumn{2}{|l|}{ Mean } & \multirow{2}{*}{$\begin{array}{l}\text { Std. } \\
\text { Deviation }\end{array}$} & \multirow{2}{*}{ Variance } \\
\hline & & & & Statistic & Std.Error & & \\
\hline Nationality & $\begin{array}{l}\text { Arabic } \\
136(37.8)\end{array}$ & \multicolumn{2}{|l|}{$\begin{array}{l}\text { Foreign } \\
224(62.2)\end{array}$} & 1.62 & 0.026 & 0.486 & 0.236 \\
\hline Gender & $\begin{array}{l}\text { Male } \\
167(46.4)\end{array}$ & \multicolumn{2}{|l|}{$\begin{array}{l}\text { Female } \\
193(63.6)\end{array}$} & 1.54 & 0.027 & 0.505 & 0.255 \\
\hline Age & $\begin{array}{l}18-25 \\
97(26.9) \\
\end{array}$ & $\begin{array}{l}26-35 \\
108(30.0) \\
\end{array}$ & $\begin{array}{l}\text { Over } 35 \\
155(43.1) \\
\end{array}$ & 2.16 & 0.043 & 0.822 & 0.676 \\
\hline Profession & $\begin{array}{l}\text { Education } \\
122(33.9)\end{array}$ & $\begin{array}{l}\text { Trade } \\
42(11.7)\end{array}$ & $\begin{array}{l}\text { Other } \\
\text { Fields } \\
196(54.4)\end{array}$ & 2.21 & 0.048 & 0.918 & 0.843 \\
\hline Qualification & $\begin{array}{l}\text { Less than Bachelor } \\
88(24.4)\end{array}$ & $\begin{array}{l}\text { Bachelor } \\
107(29.7)\end{array}$ & $\begin{array}{l}\text { Higher } \\
\text { than } \\
\text { Bachelor } \\
165(45.9)\end{array}$ & 2.21 & 0.043 & 0.812 & 0.659 \\
\hline Marital Status & $\begin{array}{l}\text { Single } \\
155(43.0)\end{array}$ & $\begin{array}{l}\text { Married } \\
145(40.3)\end{array}$ & $\begin{array}{l}\text { Others } \\
60(16.7)\end{array}$ & 1.74 & 0.038 & 0.727 & 0.529 \\
\hline Yearly Income & $\begin{array}{l}\text { Less than } \$ 12.000 \\
119(33.1)\end{array}$ & $\begin{array}{l}\$ 12.000- \\
\$ 24.000 \\
75(20.8) \\
\end{array}$ & $\begin{array}{l}\text { Over } \\
\$ 24.000 \\
166(46.1) \\
\end{array}$ & 2.13 & 0.046 & 0.881 & 0.777 \\
\hline Likely to travel & $\begin{array}{l}\text { Family } \\
183(50.8)\end{array}$ & $\begin{array}{l}\text { Friends } \\
128(35.6)\end{array}$ & $\begin{array}{l}\text { Alone } \\
49(13.6)\end{array}$ & 1.64 & 0.039 & 0.734 & 0.539 \\
\hline
\end{tabular}

Through analyzing the visitor profile it is clear that most of visitors to Jerash site are foreigners, and constitutes a percentage about (62.2). This emphasizes that the Jerash site relies on international tourism more than domestic or interregional tourism. 
The percentage of females (63.6) is higher than the males, and most of the visitors aged over 35 years old, and then followed by (25-35) years old. This indicates that females are more interested in cultural, heritage and archaeological tourism, and also in this age are interested to learn more about other culture. The analysis reveals that the percentage of those holding certificates higher than the bachelor's degree is (45.9) and it is the highest percentage.

This is compatible with what was mentioned by (Ko Ko \& Supinit 2016, p: 429) that it is the most of the visitors to the archaeological sites are foreigners and that the most of them have higher education, as confirmed by many studies.

The statistical results confirm that most of the visitors are single is about (43.0) from those whom their income exceed $\$ 24.000$, and their percentage (46.1). This is confirmed by the previous indicator which indicates that most of the visitors from the ages above 35 years old and from those who holding certificates higher than the bachelor's degree. Also, most of them like to travel with the family is about (50.8), then followed by those who prefer to travel with friends. Since the age over 35 explains their preference to travel with the family more than friends.

7.3. T- Test and F. Test

Table5. T- Test and F. Test Analyses of Visitor Experience

\begin{tabular}{|l|l|l|}
\hline Item & T.Sig & F.Sig \\
\hline It was a great experience. & 0.000 & 0.344 \\
\hline I felt I should have visited Jerash before. & 0.004 & 0.208 \\
\hline I felt an emotional connection with the things I saw. & 0.032 & 0.417 \\
\hline I am happy about my decision to visit Jerash. & 0.048 & 0.005 \\
\hline I felt scenes of wonder or awe. & 0.080 & 0.280 \\
\hline I had an enjoyable experience. & 0.051 & 0.015 \\
\hline I received a good knowledge about the site. & 0.040 & 0.880 \\
\hline The experience was engaging. & 0.442 & 0.737 \\
\hline The visit achieved my perceptions and expectations. & 0.001 & 0.038 \\
\hline I got value for money spent. & 0.120 & 0.000 \\
\hline I discovered some new information. & 0.002 & 0.010 \\
\hline
\end{tabular}

Table number (5) shows that the values for almost half of the questions whether in T. test, or F. test, is equal or more than (0.05), which indicates that there is an agreement in the answers between the means of Arabs and foreigners answers, and also among the means of the sub-groups answers in each main segment.

It is clear that the Arabs and foreigners agree in their answers about their experience at Jerash site. This may be due to their judgment on their experience based on the same criteria, and perceptions.

Table 6. T. Test and F. Test Analyses of Visitor Loyalty

\begin{tabular}{|l|l|l|}
\hline Item & T.Sig & F.Sig \\
\hline I will recommend close friends and relatives to visit Jerash. & 0.079 & 0.052 \\
\hline I intend to visit Jerash again. & 0.000 & 0.086 \\
\hline I will spend more time in the next visit to Jerash. & 0.000 & 0.036 \\
\hline
\end{tabular}

Table number 6 (T. Test and F. Test Analyses of Visitor Loyalty) show that the T. test for the first statement (I will recommend close friends and relatives to visit Jerash) is about (0.79), and F. test is about (0.052), all the 
results are more than $(0.05)$, this indicates that there is an agreement in the answers mean between Arabs and foreigners, and between the subgroup's answers' mean.

For the second statement (I intend to visit Jerash again), T. test is about (0.000) which indicate that there is a lack of consensus in the answers mean of the Arabs and foreigners, while F. test is about (0.086), which ensure that there is an agreement in the sub-groups answers mean.

As for the last question (I will spend more time in the next visit to Jerash), in order T. test and F. test is about (0.000) (0.036), which indicates that there is a lack of consensus in the answers mean of the Arabs and foreigners, and also in the answers mean among the sub-groups.

Therefore, we can say that the Arabs and foreigners are fully in agreement in their loyalty to Jerash site, and in their recommendation close friends and relatives to visit Jerash. But they disagree about intending to visit Jerash again, or spending more time in the next visit to Jerash. This is confirmed in the table (3) which relate to descriptive analysis for indicators of visitor loyalty, where there is dispersion in respondents' answers on this subject. This may be due to the differences in thinking and interest in priorities for both the Arabs and the foreigners. So that their loyalty to Jerash site does not mean they are certain or agree on their decision to visit Jerash again, or spending more time in the next visitation.

\subsection{Hypotheses Analysis}

Table7. Hypotheses Analysis (Correlation)

\begin{tabular}{|l|l|l|l|}
\hline Hypothesis & $\mathbf{R}$ & $\mathbf{R}^{\mathbf{2}}$ & F.Sig \\
\hline $\begin{array}{l}\text { H1: There is a good relationship between experience and } \\
\text { loyalty. }\end{array}$ & 0.687 & 0.472 & 0.000 \\
\hline
\end{tabular}

Analysis of the hypothesis shows that the correlation (R) is about (0.687), it is more than (0.5), that indicates there is a moderate relationship between experience and loyalty, and the result of $\left(\mathrm{R}^{2}\right)$ is about $(0.472)$. Upon these findings, it is clear that there is a good relationship, and the visitor's experience affect moderately with a percentage (0.472) on their loyalty, the rest of the impact on visitor loyalty is due to factors other than experience. Emphasis that the F. Sig. is $(0.000)$, it is less than $(0,05)$, which means there is a significant relationship between the experience and loyalty, Based on these results, we accept the hypothesis alternative hypothesis (There is a good relationship between experience and loyalty), and we reject the null hypothesis.

This is compatible with what was mentioned by (Chen, S. and Chen, F., 2016, p: 29) that it is indirect and not direct effects of the quality of experience that impact on behavioral intentions when mediated by perceived value and satisfaction. Overall, the relationship "experience quality $\rightarrow$ perceived value $\rightarrow$ satisfaction $\rightarrow$ behavioral intentions or loyalty.

\subsection{Results of Open-Ended Questions Are As Follows:}

Q1. How did you know about Jerash?

255 visitors out of 360 answered the question about how they know

about the site Jerash site the answers were as follow:

1- Most of the visitor (62) knew about the site through the tourist guides and books.

2- (61) Through the travel agent and tour operators.

3- (46) Through the internet and social media\& travel blogs.

4- Then follow by friends, school/university studies and trips, resident in Jerash and Jordan, family and relatives, and the last were through a TV.

Did you visit Jerash before? If so how many times?

285 visitors out of 360 answered that question, $73 \%$ of their visits were the first time.

Do you have any other comments related to facilities, services, employees or other subjects? The results were as follow 
Table 8. The visitor's comments which related to facilities, services

\begin{tabular}{|c|c|}
\hline Negative comments & Positive comments \\
\hline $\begin{array}{l}\text { - The Site needs to be cleaner (There are many } \\
\text { littering, rubbish, trash and cigarettes). } \\
\text { - The toilets and health places need to be clean. } \\
\text { - The site needs more toilets. } \\
\text { - Need more rest places and areas and parking areas. } \\
\text { - Need more Tourist advertisement campaign about } \\
\text { Jerash. } \\
\text { - Need more signs about things in the site. } \\
\text { - Need wifi service. } \\
\text { - Need more regulations to keep visitors safe. } \\
\text { - Wheelchairs should be available for the disabled. }\end{array}$ & $\begin{array}{l}\text { - Impressive and wonderful preserved Place with } \\
\text { good facilities, information. } \\
\text { - A comfortable number of visitors. } \\
\text { - Tour guides handled things well. } \\
\text { - It is most enjoyable for the first experience. } \\
\text { - Nice people and very good welcoming. }\end{array}$ \\
\hline
\end{tabular}

Table number (8) shows many positive and negative visitors comments that relate to basic services and facilities, site employees and other subjects. It is clear that most of the visitors focus on the cleanliness of sites and toilet. All those comments were taken into consideration by the researcher when preparing recommendations.

\section{Conclusion}

It is obvious from this research that there is a good experience for the visitors in the Jerash site and there is a visitor's loyalty to the site. But it is clear that the site needs more attention to upgrade the visitor experience and satisfaction, and also to raise the level of loyalty. So, the needs, desires, and aspirations of visitors should be taken into consideration when preparing future plans.

This study confirms there is a moderate relationship between experience and loyalty, and the visitor's experience affect moderately with a percentage $(0.472)$ on their loyalty, and the rest of the impact on visitor loyalty is due to factors other than experience.

Through the positive and negative comments of the Jerash site, which relate to basic services and facilities, site employees and another subject, that is clearly the most of the visitors focus on the services, and more specifically in cleanliness of sites and toilet.

There are many recommendations that must be taken into consideration by the administration of the site to upgrade the level of visitor experience and satisfaction, and also to raise the level of loyalty to the Jerash site as:

1- $\quad$ Increasing the number of toilets and rest places.

2- $\quad$ Increasing the number of parking areas.

3- $\quad$ Paying attention to the cleanliness of toilets.

4- $\quad$ Paying attention to the cleanliness of the site.

5- $\quad$ Expanding the advertising campaigns that related to Jerash site.

6- $\quad$ Increase the number of illustrations and guidance signs.

7- $\quad$ Providing an on-site internet service (Wi-Fi).

8- $\quad$ Providing wheelchairs for disabled visitors.

9- $\quad$ Providing more regulations to keep visitors safe, especially in maintenance areas.

\section{References}

Abu Rumman, M., Jawabreh, O., Alhyasat, K., \& Husam, H. (2013), The impact of work environment on the average of job turnover in five-star hotels in Al-aqaba city, Business Management and Strategy, 4(2). https://doi.org/10.5296/bms.v4i2.402.

Al Adwan, K. (2015), Historic Tourism in Arch Logistic Jerash City, Indian Journal of Applied Research, Volume: 5, Issue 5, ISSN - 2249-555X. 
Alananzeh, O., Masa'deh, R., Jawabreh, O., Al-Mahmoud, A., \& Hamada, R. (2018), The impact of customer relationship management on tourist satisfaction: The case of Radisson Blue Resort in Aqaba city, Journal of Environmental Management and Tourism, 2(26), 227-240 .

Alananzeh, O., Al-Badarneh, M., Al-Mkhadmeh, A. \& Jawabreh, O. (2018), Factors influencing MICE tourism stakeholders' decision making: The case of Aqaba in Jordan, Journal of Convention \& Event Tourism, Journal of Convention \& Event Tourism, Volume 19, - Issue 2, https://doi.org/10.1080/15470148.2018.1526152

Al-Hussein, M., Jawabreh, O., Alananzeh, O., \& Ali, M. (2015), The impact of understanding the behavior of workers on the success of management, (a case study of five star hotels in Aqaba). Journal of Management Research, 7(3), 51-70. https://doi.org/10.5296/jmr.v7i3.7115.

ALsarayreh,M.Jawabreh,O. ALkharabsheh,K. Aldahamsheh,M.(2011), Tourism Promotion through the Internet (Websites) (Jordan as a Case Study), Asian Social Science, Vol. 7, No. 6; doi:10.5539/ass.v7n6p125.

Al-Shawagfih, K., Alananzeh, O., \& Jawabreh, O. (2015), The foundations of selecting cultural tourism product in Jordan. European Scientific Journal, 11(29).

Amyan, M., \& Jawabreh, O. (2011), Mutual impact between tourism and the host community (a case study of Wadi Rum, European Journal of Social Sciences, 19(1).

Al Bayari, O. (2005), New Survey Technologies for Production of GIS Model of the Ancient Roman Jerash City in Jordan, Cipa, International Symposium, Torino, Italy.

Al Rawashdeh, S., Sadoun, B., Bayari, O. and Al Fukara, A. (2013), Archaeological Documentation Based on Geomatics Techniques for Jerash Historical Site, International Journal of Applied Science and Engineering, 3: $235-244$

Augé, C. (2013), The Time of Two Great Cities: Petra and Jerash (323 BC - 629 AD), Chapter three, Roman Arabia", Presses de l'Ifpo, p. 155-161.

Barnes, S. J., Mattsson, J., \& Sørensen, F. (2014), Destination brand experience and visitor behavior: Testing a scale in the tourism context, Annals of Tourism Research, 48, 121-139.

Bazazo, I., Alshatnawi,E., Jawabreh, O. \& Alshawagfih, K. (2017), The Effect of Adopting the International Standard (ISO 10015) in Training Programs on the Performance Quality of the Workers at the Jordanian Ministry of Tourism and Antiquities, Journal of Social Sciences (COES\&RJ-JSS), Vol.6, No.3, pp:694-708; https://doi.org/10.25255/jss.2017.6.3.694.708.

Bohm, J., Halaa, N., \& Alshawabkeh, Y. (2002), Automation in lasers Canning for Cultural Heritage Application, Institute for photogrammetry University Stuttgart, Germany.

Brakus, J. J., Schmitt, B. H., \& Zarantonello, L. (2009), Brand experience: what is it? How is it measured? Does it affect loyalty?, Journal of marketing, 73(3), 52-68.

Cole, S. T., \& Chancellor, H. C (2009), Examining the festival attributes that impact visitor experience, satisfaction, and re-visits intention, Journal of Vacation Marketing, 15(4), 323-333.

Cossío-Silva, F. J., Revilla-Camacho, M. Á., \& Vega-Vázquez, M. (2018), The tourist loyalty index: A new indicator for measuring tourist destination loyalty?,Journal of Innovation \& Knowledge, JIK-66. https://doi.org/10.1016/j.jik.2017.10.003

Chiang, Y. J. (2016), "Examining the Relationships between Destination Image, Place Attachment, and Destination Loyalty in the Context of Night Markets", International Journal of Business and Management,Vol 11,N 2, DOI:10.5539/ijbm.v11n2p11 
Chen, C. F., \& Chen, F. S. (2010), Experience quality, perceived value, satisfaction and behavioral intentions for heritage tourists, Tourism Management, 31(1), 29-35.

Damgaard, K., and Blanke, L. (2004), The Islamic Jarash Project: A Preliminary Report on the first Two Seasons of Fieldwork, issue 8, assembling- the Sheffield Graduate Journal of Archaeology, Research School of Archaeology and Archaeological Science, University of Sheffield.

Darabseh, f., (2010), a strategy for the development of a tourist trail of the Decapolis sites in northern Jordan", Ph.D. thesis, University of Birmingham, Britain.

Falk, J. H. (2016), Identity and the museum visitor experience, Routledge.

Goulding, C. (2000), The museum environment and the visitor experience, European Journal of marketing, 34(3/4), 261-278.

Jawabreh, O. (2017), Analyzing Factors Affect on Five Stars Occupational Safety in Aqaba Special Economic Zone Authority (ASEZA), Journal of Social Sciences (COES\&RJ-JSS), Vol.6,No.4,pp:802-815; https://doi.org/10.25255/jss.2017.6.4.802.815.

Jawabreh,O. (2014a),The Impact of Customer Relationship Marketing by Aqaba Economic Zone A Case Study of Five Stars Hotels, International Journal of Academic Research in Accounting, Finance and Management Sciences ,Vol. 4, No.1, http://dx.doi.org/10.6007/IJARAFMS/v4-i1/583.

Jawabreh,O., Al Sarayreh, M .(2017), Analysis of job satisfaction in the hotel industry: A study of hotels fiveStars in Aqaba special economic zone authority (AZEZA), International Journal of Applied Business and Economic Research,15 19 (Part-II), 407 - pp.389.

Jawabreh,O., Alananzeh.O., Shatnawi, H.(2015),Managing Tourism Effects for Attitudes of Jordanians Towards Tourism: The Case of Petra, European Journal of Social Sciences, Vol. 48 No 1.

Jawabreh, O., Al Jaffal, T., Abdelrazaq, H., \& Mahmoud, R. (2018). The Impact of Menus on the Customer Satisfaction in Restaurants Classified in Aqaba Special Economic Zone Authority (ASEZA), Journal of Tourism, Hospitality and Sports, 33 .

Jawabreh, O. (2017b). Distinction of Jordan as a destination for religious tourism, Journal of Environmental Management and Tourism, 6(22), 1171-1182. https://doi.org/10.14505/jemt.v8.6(22).03.

Jawabreh, O. (2017c), An exploratory study of the motives of Jordanian out bound tourism and its impact on the development of tourism in Jordan. International Journal of Applied Business and Economic Research, 15 (19 Part-II), 443-467.

Kharabsheh, A. (1980), A guide for the first diplomatic institute in Jordan, A military publication, Amman.

Khrisat, B., Hamarneh, C. \& Majalli, A. (2012), Comprehensive Approach for the Conservation of the Mosaic Floor of the Saints Cosmas and Damian Church of Jerash Greco- Roman City, Mediterranean Archaeology and Archaeometry, vol. 12, No 1, pp. 43-61.

Ko Ko, W., \&Supinit, V.(2016), Perspective of Tourist in Began Relating to Heritage Site in Myanmar, International Journal of Social Science and Humanities Research, ISSN 2348-3164 (online) Vol. 4, Issue 4, pp: (429-435), www.researchpublish.com.

Local Development Unit and the Geology researchers, Site Study of Roman Pools' Site, Partnership project for the rehabilitation of cities for economic development, www.pdffactory.com, (accessed 18 March 2018). 
Myers, D., Nicole, S., \& Shaer, M. (2010), A Didactic Case Study of Jarash Archaeological Site, Jordan: Stakeholders and Heritage Values in Site Management, The Getty conservation institute.

https://www.getty.edu/conservation/publications_resources/pdf_publications/pdf/jarash_case_study2.pdf access $28 / 3 / 2018$

Naidoo, P., Ramseook-Munhurrun, P., \& Seegoolam, P. (2011), An assessment of Visitor Satisfaction with Nature-Based Tourism Attractions, international journal of management and marketing research, volume 4, number 1 .

Omar, J,. Bushra ,A,. Ismail ,A,. Qatada,A.(2017), Assessing Factors that Prevent Female Students from Studying Hotel Management: A Case Study of the University of Jordan (Aqaba Branch) ,Journal of Management Research, Vol. 9, No. 4, https://doi.org/10.5296/jmr.v9i4.11690

Qusay ,Q. , Jawabreh,O., Bashar ,M., Rami ,M.(2018), Why Arab Societies do not Encourage the Work of Their Members in Hotels?, Modern Applied Science, Vol. 12, No. 11, https://doi.org/10.5539/mas.v12n11p259.

Shik Yoon, Y., Soo Lee, J., Ki Lee, C. (2010), Measuring Lee festival quality and value affecting visitors' satisfaction and loyalty using a structural approach, International Journal of Hospitality Management, (2010) $335-342$.

Shackley, M. (2001), managing sacred sites: Service provision and visitor experience, Cengage Learning EMEA.

Verdugo, M., Vazquez, M., García, M., Agüera, F. (2016), The relevance of psychological factors in the ecotourist experience satisfaction through eco-tourist site perceived value, Journal of Cleaner Production 124 (2016) $226-235$

Walmsley, A. (2002), Jordanian Islamic Jarash Project, A report on the 2002 field season, the Danish- Islamic Art and Archaeology Carsten Niebuhr Institute, The University of Copenhagen.

Watts, D. (1997), Boundaries and Linkages Transformations of Jerash, Jordan, case European Conference, Berlin.

WTTC (2017), Travel \& Tourism Economic Impact, Annual Research: Key Facts.

Zabkar, V., Brenc `ic, M., Dmitrovic, T. (2010), Modeling perceived quality, visitor satisfaction and behavioral intentions at the destination level, Tourism Management, 31 (2010) 537-546. 